\title{
SUPPORT AND PREVENTION TO CHILDREN AND ADULTS - VICTIMS OF TRAFFIC, VIOLENCE, DEPENDENCIES AND OTHER RISKS OF SOCIAL MARGINALIZATION
}

\author{
Venelin Terziev \\ Academician of the Russian Academy of Natural History, Moscow, Russia, Prof. D.Sc. (Ec.), D.Sc. \\ (National Security), D.Sc. (Social Activities), Ph.D., National Military University, Veliko Tarnovo, \\ Bulgaria; University of Rousse, Rousse, Bulgaria, terziev@skmat.com
}

\begin{abstract}
The paper examines activities and services in the sphere of prevention and support to children and adults victims of traffic, violence, dependencies and other risks of social marginalization. Some behavioral issues are discussed regarding investigated risks, as well as the specialized services and centers in the Republic of Bulgaria. Crisis interventions and participation of parties in it are considered from the point of view of challenges and problems in management and the application of a coordination mechanism. Recommendations are given about the processes of optimization of work on local level, municipal and regional strategies, specialized training and motivation activities.
\end{abstract}

Keywords: social marginalization, crisis intervention, risky groups.

\section{INTRODUCTION}

In investigations and assessments of risks of victims of traffic, violence, dependencies and other risks of social marginalization all the factors that could have an influence on such a behavior should be considered. For instance, the history of early childhood is examined, the availability of promising adherence is traced in connection to development of capabilities and skills of minors, and also whether there are indications for problems. That's why it is good to apply the adherence theory which explains the risky behavior. It is obvious that the roots of anti-social behavior should be sought into the complex impact of a number of factors which results in outlining two mechanisms of development of deviant identity in minors. The first one is pathological socialization, i.e. rejection and neglect in childhood which leads to psychopathological and neuropathic changes. The second one is parental inadequacy through decrease in family control and children going out on the street. In an environment with increased criminal activity there is great possibility to be involved in serious crimes. Weak control of adults on socialization is particularly prominent in extremely unfavorable conditions, for example broken family or bad environment.

From the sociological point of view the most characteristic deformations in behavior of minors are connected to the lack of an adequate self-estimate which expresses in increased anxiety, irritability, hot temper and bent for deviations. Inadequately decreased or increased self-estimate could be an essential source of tension and destabilizer of behavior because the striving after its conservation and change turns into a motif 
for a behavior aiming at lowering the tension. In cases of persons done violent crimes for instance that tension is "diluted" by various forms of verbal and physical aggression. One of the most important points is the negative social identification. Data make evidence that in cases of anti-social activities the consequences of such identification could be outlined with personal characteristics and ways of behavior, norms and values, models of behavior adopted by different sources of the social environment. And the last is usually formed in youth period when the personality is still immature and the mechanisms of protection are not developed yet, such as when in perpetrators of anti-social activities some deficits of socially acceptable qualities, features and behavioral models are found and rigidity, stereotypes of behavior and triteness of thinking are observed.

In the discussion of reproduction and transfer of deviation between generations in the scope of the community a successful approach is that focusing on both individual factors and the whole context and nature of social and interpersonal relationships. The implementation of preventive and corrective actions is growing along with the concept of the "social capital". Stimulating development of networks using and reinforcing the opportunities for help and support could embrace as many sectors of social context as all considerations implicated in educational and practical characteristics of deviant behavior.

Specialized services and activities in prevention, re-socialization and support to children and persons of the full legal age - victims of violence, traffic, as well as persons having a risky behavior and dependencies, could be examined in common because the services are connected and "cross the border" between age groups of children, youth and adults. Current study analyses data provided in regional strategies and by competent authorities in the Republic of Bulgaria as the operative statistical data provided by the Ministry of labor and social policy (presented on the tables below) and the report of the State agency for child protection about monitoring on the application of the Coordination mechanism for interactions in the work with cases of children - victims of violence or in risk of violence and for interactions in crisis interventions on which basis it makes important recommendations about optimization of work and motivation.

\section{PREVENTION AND RE-SOCIALIZATION IN REGIONAL STRATEGIES}

In Bulgarian regional strategies these services are differentiated by age and specificity of target groups and they are "entered" into the corresponding goals and the logic of the intervention. The comparative review of regional strategies in the Republic of Bulgaria shows that measures and services for risk prevention and support to children and adults - victims of violence, traffic, exploitation, lack of supervision, etc., should be developed and diversified. There are a limited number of regional strategies having them developed as a complex system of measures. In most cases those activities are just "marked" as a component of the services for children in risks.

Necessities of those heterogeneous risky groups require a broad spectrum of diversified and flexible services for prevention, as well as for overcoming the consequences for the victims of violence, neglect, different forms of exploitation, traffic, etc. The services are focused on the support for getting over and prevention of deviant behavior in children and direct work with them and their families. Along with the social work with children in risk, implemented by the Centers for social support, some other activities are envisaged as school engagement through prevention campaigns, organization of out-of-school events and training programs about the dangers and consequences of the use of drugs and alcohol, tobacco, traffic of people, sexual exploitation, provision of information on the questions about violence and neglect, etc.

Everywhere in the strategies examined the usual support measures are planned as:

Measures and activities of the department for child protection at the directorates of social assistance of the Ministry of labor and social policy;

Support from existing social services (centers of social support, centers of social rehabilitation and integration, day centers) - consultations, mediation and support to children - victims of violence, traffic and dependencies, as well as specialized programs for work with children-perpetrators of anti-social behavior, violence, risky behavior, etc.;

Activities of local commissions for fight against anti-social behavior of minors and public educators in municipalities along with departments for child protection in support of youth with deviant and risky behavior and victims of violence;

Application of the coordination mechanism of interaction in cases of work with children - victims of or in risk of violence which regulates the concrete obligations of engaged subjects in necessity of crisis intervention. The mechanism unites resources and efforts of departments for child protection, municipal representatives, regional bodies of the Ministry of interior, regional health inspections, children's general practitioners, 
regional inspectorate of the Ministry of education and science, schools, kindergartens, local commissions, court, prosecutor's office, suppliers of social services, etc. The role of the coordination mechanism approved by the State agency for child protection at the beginning of 2010 is underlined in most of the strategies.

\section{SPECIALIZED AND TARGETED SERVICES AND CENTERS}

Centers for work with children on the street- In the period 2011-2015 in the strategies under investigation a significant expansion of the service "centers for work with children on the street" is not mentioned (Table 1). Furthermore, those centers are not among the preferred services and they are planned to be of lower number and capacity in separate municipalities. That "reflux" of increased attention to them some years ago is explained by the fact that it became obvious for local parties that children on street according to the standard determinations are exception and in most often cases those are neglected children living with their families but growing on the street. Because of those reasons strategies start to envisage some modifications in activities of those centers, even significant transformations, incl. work with children in risk to get on the street or threatened by dropping out the school. In some regions the need of new centers is substantiated by the season migration of vulnerable families and children out of control in some big sea resorts where during summer a significant number of youths without supervision is observed. New centers are mostly planned for work with vulnerable groups from the communities of the gypsies. For instance, the strategy of the capital Sofia foresees provision of sustainability of those centers to non-governmental organizations funded by projects and municipal budget.

Table 1. Services and capacities of centers for work with children on the street (Data for 2015 in project)

\begin{tabular}{|c|c|c|}
\hline Year & Number of services & Capacity \\
\hline 2010 & 12 & 256 \\
\hline 2011 & 14 & 271 \\
\hline 2012 & 18 & 346 \\
\hline 2013 & 21 & 411 \\
\hline 2014 & 21 & 418 \\
\hline 2015 & 20 & 403 \\
\hline
\end{tabular}

Crisis centers- Crisis centers for rendering short-term asylum, crisis intervention, psychological support, mediation for health care, juridical and social consulting and provision of information are planned in various formats and scopes regarding target groups. Table 2 embraces crisis centers opened and planned as a state delegated activity. Mist of the innovative and alternative services offered by non-governmental organizations are not included because the strategies do not point "capacity" but a spectrum of activity and approximate number of users per year. Most of the crisis centers work on regional and municipal level in order to envelop into a network all or at least the biggest part of municipalities and settlements. Along with other services the strategies rely on the urgent reception in cases of crisis bringing out of children - victims of violence or in family crises. However, in some regions such services are not planned in the necessary volume while in others a comparatively big total capacity is foreseen and there is a great chance some additions in local strategies to be imposed.

Table 2. Crisis centers for children and adults (Data for 2015 in project)

\begin{tabular}{|c|c|c|}
\hline Year & Number of services & Capacity \\
\hline 2010 & 17 & 165 \\
\hline 2011 & 22 & 241 \\
\hline 2012 & 37 & 435 \\
\hline 2013 & 49 & 595 \\
\hline 2014 & 55 & 656 \\
\hline 2015 & 56 & 671 \\
\hline
\end{tabular}

Centers for social rehabilitation and integration- Specialized centers for consultation and re-socialization of children and adults - victims of various forms of violence, exploitation and traffic, as well as such having deviant and anti-social behavior. The services are usually provided as state-delegated activities, municipal initiatives or programs of nongovernmental organizations. The variety of centers embraces different activities 
and services for children and adults, incl. in the field of family violence, traffic, etc., as support, consultations, art-therapy, social entrepreneurship and others.

Asylums for children- The necessity of such asylums is substantiated in some of the examined regional strategies. In some of them the activities continue the previous work in the sphere while others plan opening of new asylums for children. Sometimes the services are provided by centers for temporary lodging. Depending on the specificities of the problems in some municipalities asylums are planned with a specific focus - for example in the above mentioned sea area an intermunicipal center is planned for temporary lodging of children begging and prostituting during summer in some of the resorts which will provide social, psychological and juridical consultations, prevention services and support. Besides that, other services for residential accommodation of children and youths with deviant behavior are planned in the form of specialized centers of accommodation of family type and "protected homes" some of which are in closer in their essence to the services of longer terms in the field of crisis accommodation of victims of violence and provision of support for recovery and resocialization.

Table 3. Asylums for children (Data for 2015 in project)

\begin{tabular}{|c|c|c|}
\hline Year & Number of services & Capacity \\
\hline 2010 & 6 & 95 \\
\hline 2011 & 6 & 95 \\
\hline 2012 & 9 & 127 \\
\hline 2013 & 10 & 147 \\
\hline 2014 & 10 & 147 \\
\hline 2015 & 10 & 147 \\
\hline
\end{tabular}

Prevention and support in cases of risky behavior and dependencies- In most cases the strategies rely on the services provided by existing or new social centers as centers for social support or centers for social rehabilitation and integration when the corresponding capacity and specialists are available, as well as interdepartmental structures as the municipal councils for drug substances supporting and participating in the measures of prevention and reintegration of people with dependencies. Along with the above mentioned centers for social support and centers for social rehabilitation and integration, the strategies has also included some specialized ones targeted to support and resocialization of children and adults with risky behavior and dependencies, incl. some providing labor qualifications and realization, social the rapeutical and rehabilitation services, etc.

Centers for consultations- Besides all the described in previous sections, the strategies has also planned specialized centers and services developed by non-governmental organizations and municipalities providing consultations, support and resocialization of people with deviant and risky behavior and dependencies, as advisory centers for re-socialization of persons with dependences, centers for advisory services and risk prevention in cases of prostitution, centers for persons with behavioral problems, modular intersectional and mixed services (information, advisory, educational, training and support) for the risky groups, prevention campaigns, etc.

Centers for prevention and information- Centers for prevention and information for persons with dependencies, HIV / AIDS, etc. are being developed on the municipal level as subsidiary bodies to the regional councils on drug substances and local commissions for fight against anti-social behavior of minors rendering mostly preventive, corrective and instructive services for minors.

Health and social services for prevention of HIV / AIDS and tuberculosis- They are developed in the framework of a number of programs by the Ministry of health and their role and contribution is reported in some of the regional strategies with recommendations for continuation of activities and assurance of sustainability of the programs.

Programs and services of non-governmental organization in partnerships with municipalities- Regional strategies provide evidence that the activities of nongovernmental organizations are an extremely important resource in the implementation of the policies in the field of prevention and support in cases of risky behavior 
and dependencies. The significant contribution is reported in the regional strategies paying special attention to the continuation of existing services and expansion of successful programs in non-governmental organizations for prevention, support and reintegration of persons with risky behavior and dependencies. The strategies also note the need of new initiatives as services and programs in non-governmental organizations including "mobile" social work, health consultations, direction and provision of access to social and health services, psychological and juridical advisory services, etc., as business centers, health centers for youth providing mixed health and social services and others. In some of the big municipalities (as the capital) some investigations are planned on the use of psychoactive drugs, risk factors and mechanisms initiated and conducted by non-governmental organizations in partnership with municipalities. That rich "palette" of services and initiatives in risk prevention and overcoming consequences of violence and dependencies presented in the regional strategies show the "intentions" of transfer of good practices and experience of nongovernmental organizations in municipal services and activities.

Integrated interventions for specific risky groups- In all the regional strategies the necessity of services for integration of youth left the specialized social institutions for children standing before the challenges of transition to an independent life is deduced. In that direction some typical measures are noted which to be implemented by the supportive network of services in a broad partnership with connected sectors education, employment, health care and municipal residential policies. The measures are focused on the two big problems before the youths going out of the specialized institutions: the need of adaptation to the independent living (through development of programs in the specialized institutions for gaining social skills, transition houses and houses under surveillance, activities of centers for social support and municipalities providing information, consultations, as well as actions in cases of crisis situations on the way out of the institutions rendered with decreasing intensity in proportion to the increasing independency) and support for social and labor integration (through assistance and mediation for finding a job and home provided by municipalities, non-governmental organizations and suppliers of services, programs for professional qualification and provision of employment, development and implementation of municipal programs for building up social homes, etc.). In some of the strategies some additional specific purposeful services are planned assuring support for reintegration, overcoming of poverty and social marginalization accounting also on the great opportunities provided by the operational programs.

Centers for temporary lodging- Regional strategies plan the continuation of activities of existing and establishment of new centers for temporary lodging (Table 4).

Table 4. Centers for temporary lodging (Data for 2015 in project)

\begin{tabular}{|c|c|c|}
\hline Year & Number of services & Capacity \\
\hline 2010 & 11 & 698 \\
\hline 2011 & 15 & 708 \\
\hline 2012 & 26 & 886 \\
\hline 2013 & 30 & 935 \\
\hline 2014 & 32 & 985 \\
\hline 2015 & 34 & 1010 \\
\hline
\end{tabular}

Other services for specifically vulnerable groups- In the corresponding directions of the regional strategies measures and activities in support to other risky groups are envisaged funded by municipalities, projects of non-governmental organizations or as state-delegated activities. Those include a variety of services for persons in probation and ex-prisoners, unemployed persons form vulnerable communities, long-term unemployed, victims of discrimination, immigrants and refugees, persons suffering oncological diseases, homeless people, etc. providing consultations, support for reintegration, vocational training and other courses, labor mediation and many others. Those services are much diversified in terms of profile and contents of activities but in regional strategies as a whole they are planned in a very limited volumes and they are even absent in some. Some of those services are envisaged in a broad scope for the entire region but at the same time other necessary services are fragmented in their territorial spread and supposed number of risky groups (Terziev, Georgiev, 2018a-d; Terziev, Banabakova, Georgiev, 2018e-o; Dimitrova, Georgiev, 2017a-b). 


\section{COORDINATION MECHANISM AND ITS APPLICATION IN BULGARIA}

The application of the coordination mechanism is done by teams working on the territory of the country. In an inquiry presented in the monitoring report of the State agency for child protection from 2013 about the effectiveness of its functioning the biggest part of the interviewees answer that there is a very good interactions between parties. Regular meetings are conducted embracing the multifunctional teams of the representatives from obligatory participating institutions showing a good interaction of regional institutions and administrations working in different fields, incl. both events on procedure issues and as a result of a signal or work on specific cases. The 2013 report, for example, shows that $49 \%$ of the signals is about physical violence, almost $19 \%$ about sexual violence on a child. The analysis concludes that following the necessary check-up $75 \%$ of the signals become cases. Sources of signals in cases of a child in risk are parents $(14 \%)$ and the national telephone line for children (12\%). Another significant source according to regional police departments is the educational institutions. The signals from general practitioners and healthy institutions are of extremely low number ( $1 \%$ and $5 \%$ correspondingly).

Crisis intervention- Description of situations accepted as crisis events requiring specialized psychological support embraces a broad circle of cases of violence, traumas and incidents. In crisis events the crisis interventions are conducted by a wide scope of specialists - social workers, pedagogues, psychologists, psychiatrists, inspectors, policemen, jurists. In some cases assistance is provided by the external team for crisis intervention of the State agency on child protection and National mobile group for psychological support at the Ministry of education. For $36 \%$ the regional prosecutor's office is referred and in almost the half of them (46\%) are gone to law according to the report from 2013.

Engagement, understanding the essence and participation of obligatory represented partners in interdepartmental teams on local level- The joint work of different specialists provides a multidisciplinary approach and is based on the active participation and engagement of the team members. The leading one are the departments for child protection and regional police offices. At the same time, the regional administrations point out that the engagement of the representatives of municipalities becomes more active in cases of children - victims of violence. Once more the relatively low percentage of the signals from general practitioners is underlined although those are the people very closer to the families and children in ages when a child is mostly isolated in the limits of his/her family and thus they have the opportunity and the competences to distinguish the features of violence. Another important consideration is about the role and the participation of educational institutions.

Challenges and problems in the application of the coordination mechanism- The departments for protection of children provide important information about the problems they faced - in most cases they are connected to the insufficient development of social services and the lack of specialists, especially psychologists. Some teams point out that there are no places for police protection or crisis centers, insufficient or lacking services on the territory of some municipalities, availability of non-regulated issues during the transport and transfer of children, difficulties in provision of assistance from the health institutions, etc. Other problems are connected to the work with parents and their aggressive behavior and the absence of wish to support. That raises questions regarding the statute of social workers, imposition and effectiveness of the obligatory prescriptions. Other impediments concern the human resources of the departments for child protection, the lack of enough cars to serve a few municipalities, etc. Comparatively low number interviewees point out difficulties in communication and interactions, especially considering provision of information from regional police departments and the availability of social workers in hours out of the regular working time, incl. holidays. Another hindrance is noted to be the lack of court doctors and funding and hence on the procedure of the necessary medical reviews. However, the biggest part of the interviewees from the interdepartmental teams on local level think that the introduction of the mechanism for coordination significantly improves communication and effectiveness of work.

The cases when there are not registered signals (as in the region of Vidin) lead to the implication that the procedures are signed only formally and that there is a need of additional help and support in order to identify what impedes the joint work of engaged participants (Terziev, Banabakova, Arabska, 2018p; Terziev, Arabska, Banabakova, Kovalyov, 2018q; Terziev, Arabska, Banabakova, Ignatova, Kovalyov, 2018r; Terziev, Arabska, Banabakova, 2018s; Terziev, 2016a; Terziev, 2017c; Terziev, Radev, Arabska, Dimitrovski, 2017d; Terziev, 2017e).

\section{CONCLUSION}

Bearing in mind the necessity the work on the local level to be properly optimized and supported some actions should be undertaken in the following directions: 
- In the forthcoming update of regional and municipal strategies every one municipality should make analyses of existing services for children suffered violence and on the basis of the concrete needs to determine a "minimal package" of social services for work with children and families while on the regional level at least one crisis center should be established.

- Provision of joint trainings for the representatives in interdepartmental teams on local level targeted to the peculiarities of work and the interactions between them.

- Planning and implementation of measures directed to encouragement of doctors-general practitioners for timely signaling.

- Provision of regular monitoring on the social workers.

- Provision of necessary material and technical resources for relevant social work.

- Development and application of programs for work with perpetrators of violence.

The outlined organizational problems and difficulties could be solved in the teams on local level through timely provision of information and feedback. At the same time there is a need of meetings, seminars and trainings explaining and fostering the opportunities and interactions between competent institution.

\section{REFERENCE LIST}

Terziev, V., Georgiev, M. (2018a). A strategic framework for the development of social entrepreneurship in Bulgaria. // Knowledge - International Journal, August 2018, Institute of Knowledge Management, Skopje, Macedonia, 25, 2018, N1, pp. 23-34, ISSN 1857-923X (for e-version), ISSN 2545 - 4439 (for printed version).

Terziev, V., Georgiev, M. (2018b). Support for the development of social entrepreneurship in Bulgaria. // Knowledge - International Journal, September 2018, Institute of Knowledge Management, Skopje, Macedonia, 26, 2018, N1, pp.57-74, ISSN 1857-923X (for e-version), ISSN 2545 - 4439 (for printed version).

Terziev, V., Georgiev, M. (2018c). Characteristics of the Social Assistance System. // Sbornik dokladi ot godishna universitetska nauchna konferentsiya 14-15 yuni 2018 g., Elektronno izdanie, NVU Vasil Levski- Veliko Tarnovo, Veliko Tarnovo, 2018, str. 959-969, ISBN 978-619-7246-20-9 (online e-book), ISSN 2367-7481 (Терзиев, В., Георгиев, М. Характеристики на системата за социално подпомагане. // Сборник доклади от годишна университетска научна конференция 14-15 юни 2018 г., Електронно издание, НВУ Васил Левски- Велико Търново, Велико Търново, 2018, стр. 959-969, ISBN 978-619-7246-20-9 (online e-book), ISSN 2367-7481).

Terziev, V., Georgiev, M. (2018d). Social Protection of Vulnerable Populations in Bulgaria. // Sbornik dokladi ot godishna universitetska nauchna konferentsiya 14-15 yuni 2018 g., Elektronno izdanie, NVU Vasil Levski- Veliko Tarnovo, Veliko Tarnovo, 2018, str. 970-975, ISBN 978-619-7246-20-9 (online e-book), ISSN 2367-7481 (Терзиев, В., Георгиев, М. Социална защита на уязвимите групи от населението в България. // Сборник доклади от годишна университетска научна конференция 14-15 юни 2018 г., Електронно издание, НВУ Васил Левски- Велико Търново, Велико Търново, 2018, стр. 970-975, ISBN 978-619-7246-20-9 (online e-book), ISSN 2367-7481).

Terziev, V., Banabakova, V., Georgiev, M. (2018e). Modern dimensions of social policies. // International journal scientific papers Vol 23.4 Promoted in Budva, Montenegro 24-27.05.2018, IKM - Skopje, 23, 2018, N 4, pp. 935-944, ISSN 1857-923X (for e-version) ISSN 2545- 4439 (for printed version).

Terziev, V., Banabakova, V., Georgiev, M. (2018f). Social support as part of social policy. // International journal scientific papers Vol 23.4 Promoted in Budva, Montenegro 24-27.05.2018, IKM - Skopje, 23, 2018, N 4, pp. 973-980, ISSN 1857-923X (for e-version) ISSN 2545 - 4439 (for printed version).

Terziev, V., Banabakova, V., Georgiev, M. (2018g). Structure of the social welfare system in Bulgaria. // International journal scientific papers Vol 23.4 Promoted in Budva, Montenegro 24-27.05.2018, IKM Skopje, 23, 2018, N 4, pp. 1275-1281, ISSN 1857-923X (for e-version) ISSN 2545 - 4439 (for printed version).

Terziev, V., Banabakova, V., Georgiev, M. (2018h). Role and place of social programing in public 
governance. // Mizhnarodnoï naukovo-praktichnoï konferentsiï «Zabezpechennya stalogo rozvitku ekonomiki: problemi, mozhlivosti, perspektivi» (16-17 lyutogo 2018 roku, m. Uzhgorod), Ministerstvo osviti i nauki Ukraïni Uzhgorodsykiy natsionalyniy universitet, 2018, s.93-98, ISBN 978-966-916-488-9 (Terziev, V., Banabakova, V., Georgiev, M. Role and place of social programing in public governance. // Міжнародної науково-практичної конференції «Забезпечення сталого розвитку економіки: проблеми, можливості, перспективи» (16-17 лютого 2018 року, м. Ужгород), Міністерство освіти і науки України Ужгородський національний університет, 2018, с.93-98, ISBN 978-966-916-488-9).

Terziev, V., Banabakova, V., Georgiev, M. (2018i). Social program as a product of social programming. // Mizhnarodnoï naukovo-praktichnoï konferentsiï «Zabezpechennya stalogo rozvitku ekonomiki: problemi, mozhlivosti, perspektivi» (16-17 lyutogo 2018 roku, m. Uzhgorod), Ministerstvo osviti i nauki Ukraïni Uzhgorodsykiy natsionalyniy universitet, 2018, s. 99-104, ISBN 978-966-916-488-9 (Terziev, V., Banabakova, V., Georgiev, M. Social program as a product of social programming. // Міжнародної науково-практичної конференції «Забезпечення сталого розвитку економіки: проблеми, можливості, перспективи» (16-17 лютого 2018 року, м. Ужгород), Міністерство освіти і науки України Ужгородський національний університет, 2018, с. 99-104, ISBN 978-966-916-488-9).

Terziev, V., Banabakova, V., Georgiev, M. (2018j). Social efficiency as a measure of social activities. // Mizhnarodnoï naukovo-praktichnoï konferentsiï «Zabezpechennya stalogo rozvitku ekonomiki: problemi, mozhlivosti, perspektivi» (16-17 lyutogo 2018 roku, m. Uzhgorod), Ministerstvo osviti i nauki Ukraïni Uzhgorodsykiy natsionalyniy universitet, 2018, s. 104-109, ISBN 978-966-916-488-9 (Terziev, V., Banabakova, V., Georgiev, M. Assessment of the effectiveness of social programing. // Міжнародної науково-практичної конференції «Забезпечення сталого розвитку економіки: проблеми, можливості, перспективи» (16-17 лютого 2018 року, м. Ужгород), Міністерство освіти і науки України Ужгородський національний університет, 2018, с. 110-115, ISBN 978-966-916-4889).

Terziev, V., Banabakova, V., Georgiev, M. (2018k). Social activity of human resource as a basis of effective social policy. // Mizhnarodnoï naukovo-praktichnoï konferentsiï «Zabezpechennya stalogo rozvitku ekonomiki: problemi, mozhlivosti, perspektivi» (16-17 lyutogo 2018 roku, m. Uzhgorod), Ministerstvo osviti i nauki Ukraïni Uzhgorodsykiy natsionalyniy universitet, 2018, s. 116-121, ISBN 978-966-916488-9 (Terziev, V., Banabakova, V., Georgiev, M. Social activity of human resource as a basis of effective social policy. // Міжнародної науково-практичної конфреренції «Забезпечення сталого розвитку економіки: проблеми, можливості, перспективи» (16-17 лютого 2018 року, м. Ужгород), Міністерство освіти і науки України Ужгородський національний університет, 2018, с. 116-121, ISBN 978-966-916-488-9).

Terziev, V., Banabakova, V., Georgiev, M. (2018I). Strategic advantages of an active social program. // Міжнародної науково-практичної конфреренції «Забезпечення сталого розвитку економіки: проблеми, можливості, перспективи» (16-17 лютого 2018 року, м. Ужгород), Міністерство освіти і науки України Ужгородський національний університет, 2018, с. 122-127, ISBN 978-966-916-4889 (Terziev, V., Banabakova, V., Georgiev, M. Strategic advantages of an active social program. // Міжнародної науково-практичної конференції «Забезпечення сталого розвитку економіки: проблеми, можливості, перспективи» (16-17 лютого 2018 року, м. Ужгород), Міністерство освіти і науки України Ужгородський національний університет, 2018, с. 122-127, ISBN 978-966-916-4889).

Terziev, V., Banabakova, V., Georgiev, M. (2018m). Assessment of the effectiveness of social programming. // Mizhnarodnoï naukovo-praktichnoï konferentsiï «Zabezpechennya stalogo rozvitku ekonomiki: problemi, mozhlivosti, perspektivi» (16-17 lyutogo 2018 roku, m. Uzhgorod), Ministerstvo osviti i nauki Ukraïni Uzhgorodsykiy natsionalyniy universitet, 2018, s. 127-131, ISBN 978-966-916-488-9 (Terziev, V., Banabakova, V., Georgiev, M. Assessment of the effectiveness of social programming. // Міжнародної науково-практичної конфреренції «Забезпечення сталого розвитку економіки: проблеми, можливості, перспективи» (16-17 лютого 2018 року, м. Ужгород), Міністерство освіти і науки України Ужгородський національний університет, 2018, с. 127-131, ISBN 978-966-916-4889).

Terziev, V., Banabakova, V., Georgiev, M. (2018n). The social program as a part of development strategies. // Mizhnarodnoï naukovo-praktichnoï konferentsiï «Zabezpechennya stalogo rozvitku ekonomiki: problemi, mozhlivosti, perspektivi» (16-17 lyutogo 2018 roku, m. Uzhgorod), Ministerstvo osviti i nauki Ukraïni Uzhgorodsykiy natsionalyniy universitet, 2018, s. 132-137, ISBN 978-966-916-488-9 (Terziev, V., Banabakova, V., Georgiev, M. The social program as a part of development strategies. // Міжнародної науково-практичної конференції «Забезпечення сталого розвитку економіки: 
проблеми, можливості, перспективи» (16-17 лютого 2018 року, м. Ужгород), Міністерство освіти і науки України Ужгородський національний університет, 2018, с. 132-137, ISBN 978-966-916-4889).

Terziev, V., Banabakova, V., Georgiev, M. (20180). Social programming as a possibility to increase social efficiency. // Mizhnarodnoï naukovo-praktichnoï konferentsiï «Zabezpechennya stalogo rozvitku ekonomiki: problemi, mozhlivosti, perspektivi» (16-17 lyutogo 2018 roku, m. Uzhgorod), Ministerstvo osviti i nauki Ukraïni Uzhgorodsykiy natsionalyniy universitet, 2018, s. 137-142, ISBN 978-966-916488-9 (Terziev, V., Banabakova, V., Georgiev, M. Social programming as a possibility to increase social efficiency. // Міжнародної науково-практичної конференції «Забезпечення сталого розвитку економіки: проблеми, можливості, перспективи» (16-17 лютого 2018 року, м. Ужгород),

Міністерство освіти і науки України Ужгородський національний університет, 2018, с. 137-142, ISBN 978-966-916-488-9).

Dimitrova, P., Georgiev, M. (2017a). Model of methodology for determining the needs of continuing vocationaltraining work specialists providing social services. // Innovatsii, tehnologii, nauka. Sbornik statey Mezhdunarodnoy nauchno - prakticheskoy konferentsii 25 yanvarya 2017 g., NITS Aeterna Permy, Chasty 4, 2017, s. 204-235, ISBN 978-5-906925-99-2, ISBN 978-5-00109-000-7 (Dimitrova, P., Georgiev M. Model of methodology for determining the needs of continuing vocationaltraining work specialists providing social services. // Инновации, технологии, наука. Сборник статей Международной научно - практической конференции 25 января 2017 г., НИЦ Аэтерна Пермь, Часть 4, 2017, с. 204-235, ISBN 978-5-906925-99-2, ISBN 978-5-00109-000-7).

Dimitrova, P., Georgiev, M. (2017b). Research, identification and monitoring of the needs of occupational training of social activities experts. // Innovatsii, tehnologii, nauka. Sbornik statey Mezhdunarodnoy nauchno - prakticheskoy konferentsii 25 yanvarya 2017 g., NITS Aeterna Permy, Chasty 4, 2017, s. 235-258, ISBN 978-5-906925-99-2, ISBN 978-5-00109-000-7 (Dimitrova, P., Georgiev M. Research, identification and monitoring of the needs of occupational training of social activities experts. // Инновации, технологии, наука. Сборник статей Международной научно - практической конфреренции 25 января 2017 г., НИЦ Аэтерна Пермь, Часть 4, 2017, с. 235-258, ISBN 978-5906925-99-2, ISBN 978-5-00109-000-7).

Terziev, V., Banabakova, V., Arabska, E. (2018p). The experience of the centres for provision of integrated employment and social assistance services in Bulgaria. // Upravlenie i Obrazovanie, Universitet "Prof. d-r Asen Zlatarov", Burgas, 14, 2018, N 1, str.5-14, ISSN 13126121. (Terziev, V., Banabakova, V., Arabska, E. The experience of the centres for provision of integrated employment and social assistance services in Bulgaria. // Управление и Образование, Университет “Проф. д-р Асен Златаров", Бургас, 14, 2018, N 1, стр.5-14, ISSN 13126121).

Terziev, V., Arabska, E., Banabakova, V., Kovalyov, E. (2018q). Bolgarsko-Rossiyskoe sotrudnichestvo v oblasti proektirovaniya i realizatsii mezhdunarodnayh setevayh obrazovatelynayh programm. // Sozdanie komfortnoy sreday sotsializatsii uchashtihsya, studentov i uchyonayh, Akademiya za inovatsii i ustoychivost - Plovdiv, Balgariya, 2018, str. 65-69, ISBN 978-619-7246-17-9 (print) ISBN 978-619-7246-18-6 (DVD). Терзиев, В., Арабска, Е., Банабакова, В. Ковалёв, Э. БолгарскоРоссийское сотрудничество в области проектирования и реализации международных сетевых образовательных программ. // Создание комфортной среды социализации учащихся, студентов и учёных, Академия за иновации и устойчивост - Пловдив, България, 2018, стр. 65-69, ISBN 978-619-7246-17-9 (print) ISBN 978-619-7246-18-6 (DVD).

Terziev, V., Arabska, E., Banabakova, V., Ignatova, M., Kovalyov, E. (2018r). Vliyanie tvorchestva G. V. Sviridova na kachestvo sotsializatsii studencheskoy molodyozhi. // Sozdanie komfortnoy sreday sotsializatsii uchashtihsya, studentov i uchyonayh, Akademiya za inovatsii i ustoychivost - Plovdiv, Balgariya, 2018, str. 71-80, ISBN 978-619-7246-17-9 (print) ISBN 978-619-7246-18-6 (DVD). Терзиев, В., Арабска, Е., Банабакова, В., Игнатова, М., Ковалёв, Э. Влияние творчества Г. В. Свиридова на качество социализации студенческой молодёжи. // Создание комфортной среды социализации учащихся, студентов и учёных, Академия за иновации и устойчивост - Пловдив, България, 2018, стр. 71-80, ISBN 978-619-7246-17-9 (print) ISBN 978-619-7246-18-6 (DVD).

Terziev, V., Arabska, E., Banabakova, V. (2018s). Sotsialyno-ekonomicheskoe polozhenie nezashtishtyonnayh sloyov naseleniya. // Sozdanie komfortnoy sreday sotsializatsii uchashtihsya, studentov i uchyonayh, Akademiya za inovatsii i ustoychivost - Plovdiv, Balgariya, 2018, str. 87-89, ISBN 978-619-7246-17-9 (print) ISBN 978-619-7246-18-6 (DVD). Терзиев, В., Арабска, E., Банабакова, В. Социально-экономическое положение незащищённых слоёв населения. // 
Создание комфортной среды социализации учащихся, студентов и учёных, Академия за иновации и устойчивост - Пловдив, България, 2018, стр. 87-89, ISBN 978-619-7246-17-9 (print) ISBN 978-619-7246-18-6 (DVD).

Terziev, Venelin. (2016a). Process of deinstitutionalization of children at risk in Bulgaria. // Fifth Annual International Research-to-Practice Conference «Early Childhood Care and Education» (ECCE 2016). 12-14 May, 2016, Lomonosov Moscow State University - MSU, Moscow, Russia, 2016, ISSN 23086408, pp.170-179.

Terziev, Venelin. (2017c). Prevention and support to persons at risk of social marginalization. // Children \& Schools, 39, 2017, N 4(2), pp. 1139- 1150, ISSN 1532-8759, Source Normalized Impact per Paper (SNIP): 0.400 SCImago Journal Rank (SJR): 0.211 Impact factor: 1.086 5-Yr impact factor: 1.152.

Terziev, V., Radev, D., Arabska, E., Dimitrovski, R. (2017d). Deinstitutionalisation of children as part of the development of social services in Bulgaria. // Twelfth international scientific conference Knowledge without borders, 31.3-2.4.2017, Vrnjacka Banja, Serbia, Institute of Knowledge Management, Skopje 16, 2017, N 1, ISSN 1857-923X, pp.19-28.

Terziev, Venelin. (2017e). The system of social services in Bulgaria and the process of deinstitutionalisation of children. // Proceedings of the VII International Academic Congress "Fundamental and Applied Studies in EU and CIS Countries" (United Kingdom, Cambridge, England, 26-28 February 2017). Cambridge University Press, 7, 2017, ISBN: 978-0-875-83597-4, pp.338-351, Source Normalized Impact per Paper (SNIP): 5.192 SCImago Journal Rank (SJR): 5.186 Impact factor: 7.549. 